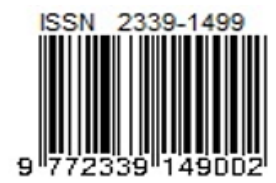

\title{
Analisis Resiko Postural Stress Pada Pekerja Di UD.XYZ Dengan Metode Rapid Upper Limb Assessment
}

\author{
Katherine Macella Silvanus Sie, Felix Valentino, Elvina Yunia Dearosa, Benedictus Rahardjo \\ Jurusan Teknik Industri, Fakultas Teknologi Industri, Universitas Kristen Petra, Surabaya - \\ Indonesia \\ Email : Katherinesie20@gmail.com
}

\begin{abstract}
UD.XYZ is a company that produce accessories for car. UD. XYZ have a factory that produce car accessories with small size like a safety belt accessories, car pillow, and tissue case. This research will be focus to analyze postural stress risk for worker that produce car accessories. This research is based on the complaints of workers who feel that some parts of their body sick and stiff because the work is a job that has a repetitive movement with almost the same position every time. The posture of the worker will be observed to determine whether the posture has a dangerous risk or not. The method used is the Rapid Upper Limb Assessment that will assess the worker's posture from the waist to the head. Research indicates that the worker's posture score is between 3 to 5 where the score is assessed to suggest that further investigation of posture is necessary. Giving a small desk to the worker and also socializing about good posture while working helps to improve the score from worker posture to 2 to 3 which means that posture can be used and minimize postural stress on the workers.
\end{abstract}

Keywords: Postural Stress, Employee, RULA Score, Body Posture

\section{Abstrak}

UD. XYZ merupakan sebuah usaha dagang yang memproduksi bergerak dalam bidang produksi aksesoris mobil. UD. XYZ memiliki pabrik yang memproduksi aksesoris mobil berukuran kecil seperti aksesori safety belt, bantalan mobil, dan tempat tissue. Penelitian ini akan berfokus untuk menganalisa resiko postural stress pada pekerja yang memproduksi aksesoris mobil. Penelitian ini dilakukan didasari oleh keluhan para pekerja yang merasa bahwa beberapa bagian tubuh mereka sakit dan pegal-pegal karena pekerjaan yang dilakukan merupakan pekerjaan yang memiliki gerakan berulang dengan posisi yang hampir sama setiap saat. Postur tubuh dari pekerja tersebut akan diamati untuk mengetahui hasil postur tubuh tersebut memiliki resiko yang berbahaya atau tidak. Metode yang digunakan adalah Rapid Upper Limb Assessment yang akan menilai postur tubuh pekerja mulai dari atas pinggang hingga kepala. Penelitian menunjukkan bahwa score postur tubuh pekerja berada diantara 3 hingga 5 dimana score ini dinilai menunjukkan bahwa perlu adanya investigasi lebih lanjut terhadap postur tubuh. Pemberian meja kecil pada pekerja dan juga sosialisasi tentang postor tubuh yang baik saat bekerja membantu memperbaiki score dari postur tubuh pekerja menjadi 2 hingga 3 yang artinya postur tubuh tersebut sudah dapat digunakan dan meminimumkan postural stress pada pekerja.

Kata Kunci: Stress Postural, Pekerja, Nilai RULA, Postur Tubuh

\section{Pendahuluan}

Bekerja merupakan suatu hal yang harus dilakukan manusia untuk memenuhi kebutuhan hidupnya. Pada saat melakukan pekerjaannya tentunya manusia perlu memiliki tubuh yang fit sehingga hasil pekerjaannya juga dapat optimal. Banyak hal yang dapat menyebabkan pekerja tidak fit dalam menjalani pekerjaannya seperti posisi tubuh dan gerakan pekerja yang berulang.

Pekerjaan yang membuat seseorang harus memiliki gerakan berulang dapat menyebabkan nyeri otot dan pegal pada beberapa bagian tubuh. Posisi tubuh yang salah saat melakukan pekerjaan juga memiliki potensi yang menyebabkan nyeri otot dan pegal oleh sebab itu, posisi tubuh saat bekerja sangatlah mempengaruhi efektifitas seseorang dalam bekerja. Posisi tubuh yang tidak sesuai dapat berpotensi memberikan postural stress pada pekerja.

Sikap kerja yang sering dilakukan oleh manusia dalam melakukan pekerjaan antara lain duduk, berdiri, membungkuk, jongkok, berjalan dan lain-lain. (Nurmianto, 2008) Sikap kerja tersebut dilakukan tergantung dari kondisi dalam sistem kerja yang ada. Sikap kerja duduk merupakan salah satu sikap kerja yang paling sering dilakukan. Duduk memerlukan lebih sedikit energi daripada berdiri, karena hal itu dapat mengurangi banyaknya beban otot statis pada kaki. Sikap duduk yang keliru merupakan penyebab adanya masalah punggung 
(Nurmianto, 2008).

UD. XYZ merupakan perusahaan yang bergerak dalam bidang konfeksi yaitu memproduksi aksesoris mobil yang terbuat dari kain. Beberapa contoh produk yang dihasilkan dari perusahaan ini seperti bantalan mobil, aksesoris safety belt, tempat tissue dan lainnya. Perusahaan ini hanya melakukan perakitan dalam produksi yang dilakukan Terdapat 4 bagian pekerjaan dalam membuat aksesoris mobil yang akan diamati dalam penelitian ini adalah pekerja yang menjahit kain, pekerja yang memasukkan dakron kedalam bantalan kain, menjahit bagian akhir, dan memotong kain.

Berdasarkan wawancara yang dilakukan kepada pekerja pada UD. XYZ, pekerja ratarata mengeluhkan sakit pinggang, nyeri punggung, pegal-pegal dan sakit disekitar leher karena pekerjaan yang mereka lakukan setiap harinya merupakan gerakan berulang dan duduk dalam jangka wakut yang lama pula. Pengamatan juga dilakukan pada pekerja tersebut dimana hasilnya mereka posisi tubuh mereka saat bekerja cukup bungkuk dan bagian kepala mereka juga sering menunduk. Posisi tubuh yang tidak baik dapat menyebabkan beberapa bagian tubuh lainnya terkena dampak seperti nyeri dan sakit, oleh sebab itu pada penelitian ini akan dilakukan perancangan perbaikan posisi tubuh pekerja pada UD. XYZ untuk mengurangi tingkat postural stress pekerja. Kesesuaian posisi tubuh pekerja dapat diukur menggunakan metode Rapid Upper Limb Assesment. Metode ini akan memberikan score pada posisi tubuh pekerja untuk mengetahui tingkat bahaya dari postur tersebut.

\section{Metode Penelitian}

Penelitian yang dilakukan pada UD. $X Y Z$ dilakukan dengan melalui beberapa tahapan yaitu melakukan wawancara, pengambilan data, dan observasi pada pekerja. Tahapan penelitian diawali dengan mengidentifikasi masalah dan kemudian melakukan studi literatur. Wawancara dilakukan kepada pekerja UD. XYZ untuk mengetahui keluhan yang dimiliki pekerja yang setelah itu akan dilakukan pengambilan data untuk mengukur score postur tubuh awal pekerja. Data yang dikumpulkan adalah pekerja yang menjahit kain, pekerja yang memasukkan dakron kedalam bantalan, pekerja yang memotong kain dan pekerja yang menjahit bagian akhir. Setelah mengetahui score awal posisi tubuh pekerja maka dilakukan pengamatan pada pekerja dengan tujuan untuk mengetahui kebiasaan yang dilakukan pekerja untuk memperbaiki posisi tubuhnya untuk mengurangi postural stress pada tubuh mereka. Perbaikan kemudian diterapkan dan diambil lagi data postur tubuh setelah perbaikan untuk 150 mengetahui perubahan score postur tubuh perbaikan dan sebelum perbaikan, sehingga dapat dibuat kesimpulan postur tubuh terbaik yang dapat digunakan oleh pekerja di UD. XYZ. Alur dari tahapan penelitian ini dapat dilihat pada Gambar 1.

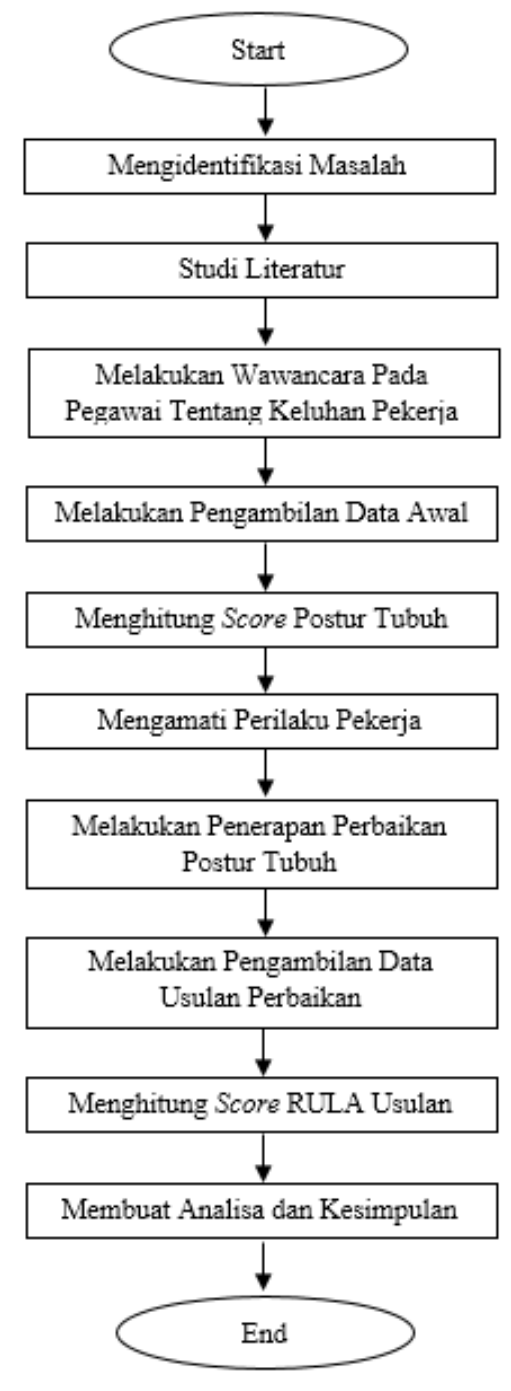

Gambar 1. Alur Tahapan Penelitian

\section{Postural Stress}

Postural Stress adalah beban pada tubuh manusia akibat postur tubuh yang kurang tepat yaitu kecenderungan orientasi bagian tubuh satu dengan lainnya pada suatu waktu (Grieve dan Pheasabt, 1982, as cited in Library Binus, 2007). Postur yang tidak tepat seperti gerakan berulang, waktu yang lama di posisi yang sama, dan gerakan yang membebankan tubuh merupakan penyebab dari postural stress. Postur tubuh statis memberikan resiko postural stress yang lebih besar, dibandingkan postur tubuh yang dinamis.

\section{Rapid Upper Limb Assessment}

Rapid Upper Limb Assessment (RULA) adalah sebuah metode survei yang dikembangkan oleh Dr. Lynn McAtamney dan Dr. Nigel Corlett pada tahun 1993 di Nottingham, Inggris. RULA dikembangkan untuk kegunaan investigasi 
ergonomi pada tempat kerja, dimana dapat diketahui ada atau tidaknya resiko postural stress bagian atas pada pekerja.

Analisa RULA dapat dilakukan sebelum dan sesudah demonstrasi untuk mengetahui apakah resiko cedera sudah berkurang. RULA digunakan dengan cara mengevaluasi postur tubuh, kekuatan yang dibutuhkan dan gerakan otot pekerja pada saat sedang bekerja Terdapat lima faktor eksternal yang dapat menjadi faktor resiko yang berhubungan dengan terjadinya cedera pada tubuh bagian atas, yaitu jumlah gerakan, kerja otot statis, beban, dimensi peralatan, dan lama kerja tanpa istirahat.

Pada metode RULA, penilaian dipengaruhi oleh penggunaan otot dan beban eksternal aktivitas kerja. Penilaian terhadap tubuh dibagi menjadi 2 segmen yaitu segmen $A$ dan segmen $B$. Segmen A menilai postur tubuh bagian pergelangan tangan dan lengan, sedangkan segmen $B$ menilai postur tubuh bagian leher, tubuh dan kaki. Score yang diperoleh dari segmen A dan segmen B akan disatukan pada segmen $C$ untuk memperoleh score akhir yang akan menentukan besar kecilnya resiko postural stress yang timbul dari postur tubuh yang dinilai (Ergoplus, 2016).

Penilaian postur kerja pada masing-masing bagian tubuh tersebut didasarkan pada posturpostur yang sudah ditetapkan pada RULA employee assesment worksheet. Score akhir yang diperoleh dari segmen $C$ akan menunjukkan besarnya postural stress atau level resiko pada pekerja dengan posisi tubuh saat itu. Level resiko dari hasil penilaian RULA dapat dilihat pada Gambar 2.

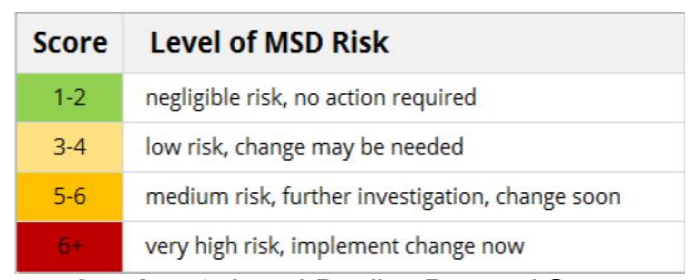

Gambar 2. Level Resiko Postural Stress

(Sumber: http://ergo-plus.com/rula-assessment-toolguide)

\section{Cumulative Trauma Disorders}

Sikap kerja duduk menjadi dasar tenaga kerja mengalami gejala Cumulative Trauma Disorders (CTDs). CTDs dapat diartikan sebagai Kerusakan Trauma Kumulatif, yang timbul karena terkumpulnya kerusakankerusakan kecil akibat trauma berulang yang membentuk kerusakan yang cukup besar dan menimbulkan rasa sakit. Hal ini sebagai akibat penumpukan cedera kecil yang setiap kali tidak sembuh total dalam jangkah waktu tertentu, yang diekspresikan sebagai rasa nyeri, kesemutan, pembengkakan, dan gejala lainnya (Budiono \& Jusuf, 2003).
Sikap kerja duduk yang kurang baik atau salah akan menyebabkan berbagai masalah terutama yang berhubungan dengan tulang belakang, karena tekanan pada tulang belakang akan meningkat pada saat duduk, bila dibandingkan dengan saat berdiri maupun berbaring (Purwanto, Mulyati, \& Saroyo, 2004).

CTDs juga dapat ditimbulkan dari tenaga kerja yang melakukan pekerjaan dengan posisi postur tubuh dan pergelangan tangan yang kurang baik serta harus melakukan pekerjaan yang berulang-ulang pada hanya satu jenis otot (Hastuti, 2009). Sikap tubuh yang dipaksakan adalah salah satu penyebab umum CTDs. Kemunculannya sering tidak disadari sampai terjadinya inflamasi, syaraf nyeri dan mengerut, atau aliran darah tersumbat. CTDs biasanya muncul dalam bentuk sindrom terowongan carpal (carpal tunnel syndrome), tendinitis, tenosynovitis, dan bursitis (Tayyari \& Smith, 1997).

\section{Hasil dan Pembahasan}

Pengamatan terhadap postur pekerja dilakukan kepada empat orang pekerja yang melakukan jenis pekerjaan yang berbeda-beda. Jenis pekerjaan yang dilakukan diantaranya adalah menjahit kain, memotong kain, memasukkan dakron ke dalam bantalan, dan menjahit bantalan. Seluruh kegiatan tersebut diperlihatkan pada Gambar 3 mulai dari kiri atas hingga kanan bawah.

Pengambilan data dilakukan dengan mengambil foto setiap bagian pekerja di UD. $X Y Z$. Pengambilan gambar ini digunakan untuk menentukan level resiko dari pekerja. Level resiko ini didapatkan dari penilaian terhadap posisi tubuh saat bekerja yang dibagi dalam 2 segmen $A$ dan $B$, pada segmen akhir yaitu segmen $C$ adalah hasil dari level resiko pekerja saat melakukan pekerjaannya.

Setiap segmen memiliki fokus pengukuran masing-masing. Pada segmen $A$ akan fokus bagian tangan dan lengan, segmen $B$ fokus pada bagian leher, punggung, dan kaki, sedangkan segmen $\mathrm{C}$ merupakan hasil akhir dari penilaian metode RULA. Pengukuran ini menyesuaikan dengan tabel RULA yang dibuat oleh McAtamney dan Corlettdan dalam jurnalnya yang berjudul RULA: a survey method for the investigation of work-related upper limb disorders. Applied Ergonomics pada tahun 1993. 


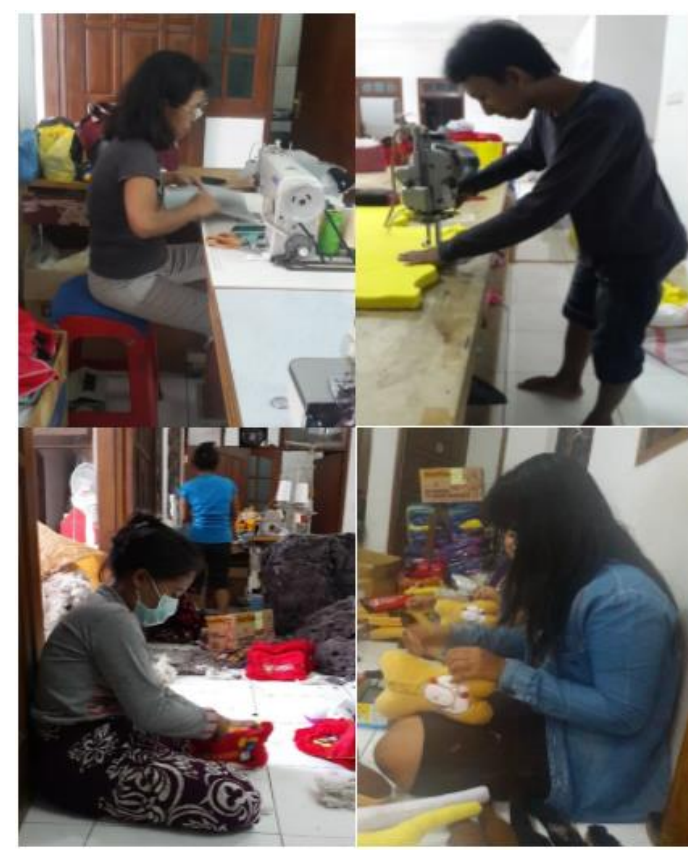

Gambar 3. Kegiatan Pekerja di UD. XYZ

Penilaian pada posisi tubuh pekerja dapat dilihat pada RULA employee assessment worksheet (Ergoplus, 2016). Foto saat bekerja tersebut akan dinilai dengan mengukur sudutsudut pada beberapa bagian tubuh yang dibutuhkan pada pengukuran menggunakan metode RULA. Beberapa penilaian pada RULA juga membutuhkan pengamatan pada gerakan, posisi, dan beban alat saat melakukan pekerjaan.

\section{Hasil Pengukuran Postur Tubuh Awal}

Pengukuran pada pekerja dilakukan menggunakan metode RULA yang setiap poin pada posisi tubuh dilihat dari data foto yang diambil sebelumnya saat pekerja melakukan kegiatan pekerjaannya seperti biasa. Foto tersebut kemudian dianalisa dan diberi penilaian score RULA untuk mengetahui resiko postural stress pada pekerja tersebut. Data foto pada pekerja tersebut dapat dilihat pada Gambar 3.

Pengukuran awal pada pekerja yang menjahit kain menunjukkan bahwa posisi tubuh pekerja yang menjahit sudah cukup tegak hanya saja kepalanya cukup menunduk yang membuat total score pada pengukuran adalah 3 yang artinya postur pekerja tersebut memiliki resiko postural stress yang kecil dan perbaikan usulan terhadap postur tubuh tersebut mungkin diperlukan.

Pengukuran berikutnya dilakukan pada pekerja yang memotong kain posisi tubuh pekerja yang momotong kain saat bekerja cukup bungkuk dan bagian lehernya juga menunduk, hal ini membuat hasil pengukuran postur tubuh pekerja ini cukup buruh yaitu 5 . Score ini menunjukkan bahwa postur pekerja tersebut memiliki resiko postural stress menengah, dan membutuhkan investigasi serta perubahan dengan segera.

Postur tubuh pekerja yang memasukkan dakron kedalam bantalan kain cukup membungkuk dan bagian kepalanya juga menunduk, hal ini juga menunjjukkan adanya indikasi postural stress pada pekerja yang memasukkan dakron kedalam kain bantalan. Hasil dari score RULA pekerja ini adalah 4 yang artinya perlu ada investigasi lebih lanjut dari posisi bekerja yang dilakukan pekerja yang memasukan dakron kedalam kain.

Pekerja yang menjahit bantalan kain bagian akhir memiliki postur tubuh yang hampir mirip dengan pekerja yang memasukkan dakron kedalam kain bantalan. Hasil ini diperkuat dengan jumlah score RULA yang sama yaitu 4 , yang memiliki arti bahwa perlu ada investigasi lebih lanjut dari posisi bekerja yang dilakukan pekerja yang memasukan dakron ke dalam kain.

Keseluruhan hasil penilaian Score RULA adalah 3-5 poin yang artinya postur tubuh pekerja tersebut membutuhkan investigasi lebih lanjut karena berpotensi memberikan postural stress pada pekerja. Hasil Score yang semakin tinggi mengindikasikan semakin besarnya resiko postural stress pada pekerja tersebut dalam hal ini adalah pekerja yang memotong kain. Hasil pengolahan postur tubuh pekerja dapat dilihat pada tabel 1 .

Tabel 1. Hasil Pengolahan Postur Kerja dengan Metode RULA

\begin{tabular}{|c|c|c|c|}
\hline No & $\begin{array}{c}\text { Aktivitas } \\
\text { Kerja }\end{array}$ & $\begin{array}{c}\text { Skor } \\
\text { Akhir }\end{array}$ & $\begin{array}{c}\text { Level Resiko \& } \\
\text { Tindakan }\end{array}$ \\
\hline 1 & $\begin{array}{c}\text { Menjahit } \\
\text { kain }\end{array}$ & 3 & $\begin{array}{c}\text { Level kecil dan } \\
\text { diperlukan tindakan } \\
\text { perbaikan postur } \\
\text { kerja beberapa } \\
\text { waktu ke depan }\end{array}$ \\
\hline 2 & $\begin{array}{c}\text { Memotong } \\
\text { kain }\end{array}$ & 5 & $\begin{array}{c}\text { Level sedang dan } \\
\text { diperlukan tindakan } \\
\text { perbaikan postur } \\
\text { kerja dalam waktu } \\
\text { dekat }\end{array}$ \\
\hline 3 & $\begin{array}{c}\text { Memasuk- } \\
\text { kan } \\
\text { dakron ke } \\
\text { dalam } \\
\text { bantalan }\end{array}$ & 4 & $\begin{array}{c}\text { Level kecil dan } \\
\text { diperlukan tindakan } \\
\text { perbaikan postur } \\
\text { kerja beberapa } \\
\text { waktu ke depan }\end{array}$ \\
\hline 4 & $\begin{array}{c}\text { Menjahit } \\
\text { bantalan }\end{array}$ & 4 & $\begin{array}{c}\text { Level kecil dan } \\
\text { diperlukan tindakan } \\
\text { perbaikan postur } \\
\text { kerja beberapa } \\
\text { waktu ke depan }\end{array}$ \\
\hline
\end{tabular}

\section{Usulan Perbaikan dan Hasil Penilaian Postur} Kerja Baru

Perbaikan pada postur pekerja dilakukan setelah mempertimbangkan keluhan dari pekerja dan juga penilaian dari postur tubuh 
menggunakan RULA yang sebelumnya telah dilakukan. Rata-rata pekerja memiliki posisi tubuh saat bekerja dengan score 3-5 yang artinya butuh pertimbangan lebih lanjut dan analisa kembali pada postur tubuh tersebut.

Hasil postur tubuh setelah dilakukan perbaikan dan usulan dapat dilihat pada Gambar 4.

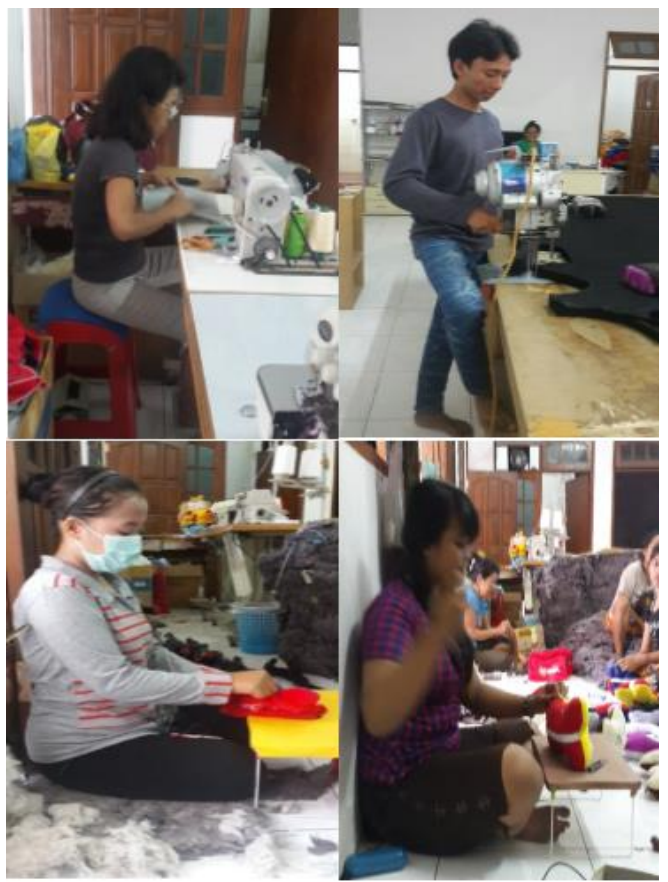

Gambar 4. Hasil penerapan usulan perbaikan pada postur tubuh pekerja UD. XYZ

Usulan tersebut antara lain:

- Tidak ada perubahan postur yang mungkin untuk dilakukan pada proses menjahit kain karena malah akan meningkatkan postural stress. Usulan perbaikan yang diberikan adalah tetap mempertahankan posisi awal tetapi dengan memberikan lebih banyak sela selama bekerja. Berikan waktu istirahat bagi tubuh, yang dimana biasanya istirahat setiap tiga jam sekali diubah menjadi setiap satu jam sekali. Penambahan sela waktu istirahat tentunya akan berdampak baik, dimana tubuh tidak terus-terusan berada pada posisi statis yang dapat menyebabkan sendi dan otot cepat lelah.

- Usulan perbaikan untuk proses memotong kain adalah posisi lengan atas lurus vertikal kebawah sehingga score yang diberikan lebih kecil yaitu +1 . Perlu juga dilakukan perbaikan pada posisi leher yang awalnya sebesar $30^{\circ}$ diubah menjadi kisaran $15^{\circ}$ sehingga score menjadi +2 . Usulan perbaikan yang diberikan pada pekerja ini menghasilkan Score akhir Rula sebesar 3. Perbandingan score segmen C antara sebelum dan sesudah perbaikan pada postur pekerja yang memotong kain dapat dilihat pada Tabel 2.
Tabel 2. Perbandingan Score Akhir sebelum dan sesudah Perbaikan pada Pekerja Memotong Kain

\begin{tabular}{|c|c|c|}
\hline \multirow{2}{*}{$\begin{array}{c}\text { Bagian } \\
\text { Tubuh }\end{array}$} & \multicolumn{2}{|c|}{ Level of Risk } \\
\cline { 2 - 3 } & Sebelum & Sesudah \\
\hline Segmen A & 4 & 3 \\
\hline Segmen B & 5 & 3 \\
\hline Segmen C & 5 & 3 \\
\hline
\end{tabular}

- Perbaikan untuk proses memasukkan dakron ke dalam bantalan dilakukan dengan memberikan tambahan meja kecil untuk menunjang lengan atas dan bawah sehingga tidak mudah lelah sehingga posisi pergelangan tangan tidak lagi membentuk sudut $15^{\circ}$ melainkan menjadi $0^{\circ}$ dengan score +1 . Dengan tambahan meja tersebut juga menyebabkan posisi neck dan trunk menjadi $10^{\circ}$ dari yang sebelumnya $30^{\circ}$ dan $20^{\circ}$, sehingga score menjadi +1 dan +1 . Score akhir RULA pada usulan perbaikan postur tubuh pekerja ini turun menjadi 2. Perbandingan score segmen $\mathrm{C}$ antara sebelum dan sesudah perbaikan pada postur pekerja yang memotong kain dapat dilihat pada Tabel 3.

Tabel 3. Perbandingan Score Akhir sebelum dan sesudah Perbaikan pada Pekerja Memasukkan Dakron ke dalam Bantalan Kain

\begin{tabular}{|c|c|c|}
\hline \multirow{2}{*}{ Bagian Tubuh } & \multicolumn{2}{|c|}{ Level of Risk } \\
\cline { 2 - 3 } & Sebelum & Sesudah \\
\hline Segmen A & 3 & 2 \\
\hline Segmen B & 4 & 2 \\
\hline Segmen C & 4 & 2 \\
\hline
\end{tabular}

- Pekerja yang menjahit bantalan juga memiliki posisi kerja yang berada di lantai sama seperti pekerja yang memasukkan dakron kedalam kain bantalan, sehingga perbaikan yang diberi adalah penambahan meja untuk menunjang tangan pekerja sehingga tidak mudah lelah. Pemberian meja ini membuat postur tubuh bagian lengan bawah membentuk sudut $90^{\circ}$ dengan score +1 , pergelangan tangan membentuk sudut $0^{\circ}$ dengan skor +1 . Penggunaan meja ini juga membuat leher membentuk sudut $10^{\circ}$ dengan score +1 . Hasil dari usulan perbaikan postur tubuh pekerj ini memiliki score akhir sebesar 2 . Perbandingan score segmen C antara sebelum dan sesudah perbaikan pada postur pekerja yang memotong kain dapat dilihat pada Tabel 4. 
Tabel 4. Perbandingan Score Akhir sebelum dan sesudah Perbaikan pada Pekerja Menjahit Bantalan

\begin{tabular}{|c|c|c|}
\hline \multirow{2}{*}{ Bagian Tubuh } & \multicolumn{2}{|c|}{ Level of Risk } \\
\cline { 2 - 3 } & Sebelum & Sesudah \\
\hline Segmen A & 3 & 2 \\
\hline Segmen B & 4 & 2 \\
\hline Segmen C & 4 & 2 \\
\hline
\end{tabular}

Penurunan level of risk menandakan bahwa usulan yang diberikan sudah tepat dan dapat menurunkan tingkat cedera pada pekerja. Hasil penurunan juga cukup besar dan diharapkan hasil ini dapat mengurangi resiko postural stress pada pekerja.

\section{Simpulan}

Penilaian postur pada awalnya menunjukkan hasil score antara $3-5$ yang menunjukkan bahwa perlu adanya investigasi lebih lanjut dan jika diperlukan maka membutuhkan perbaikan pada postur tubuh pekerja tersebut. Pekerja yang menjahit kain mendapatkan score akhir 3 dan setelah dianalisa posisi dari pekerja tersebut memang tidak dapat diubah karena sudah disesuaikan dengan meja mesin jahit pada umumnya. Perbaikan dilakukan dengan menyarankan pekerja untuk melakukan beberapa kali istirahat ketika dirasa tubuh mulai lelah. Postur tubuh pekerja yang memotong kain memiliki score awal 5 dan postur tubuh dapat diperbaiki, sehingga menghasilkan score akhir 3 . Pekerja pemotong kain disarankan untuk beberapa kali duduk disela-sela ia bekerja karena posisi bekerjanya adalah berdiri sehingga akan lebih mudah lelah dibandingkan bekerja sambil duduk. Postur tubuh pekerja yang memasukkan dakron dengan yang menjahit bantalan bagian akhir hampir sama karena mereka sama-sama duduk dengan beralaskan lantai. Score RULA yang mereka dapatkan sebelum perbaikan adalah 4. Perbaikan postur tubuh dilakukan dengan menambah meja sehingga pekerja tidak terlalu menunduk. Hasilnya score akhir dari pekerja ini menjadi 2. Postur tubuh yang baik akan membantu pekerja untuk bekerja lebih optimal dan mengurangi kelelahan dan kemungkinan penyakit yang dapat diderita.

\section{Daftar Referensi}

Budiono, A. S., \& Jusuf, R. (2003). Bunga Rampai Hiperkes \& KK : Higine Perusahaan, Ergonomi, Kesehatan Kerja, Keselamatan Kerja. Jakarta: Universitas Diponegoro. Retrieved May 7, 2017
Ergoplus. (2016). Rula Assesment Tool Guide. Retrieved January, 2 2017, from http://ergoplus.com/rula-assessment-tool-guide/

Hastuti, R. P. (2009). Hubungan Antara Sikap Kerja Duduk Dengan Gejala Cumulative Trauma Disorders Pada Tenaga Kerja Bagian Penjahitan Konveksi Aneka GUNUNGPATI Semarang. Undergraduate Thesis, Universitas Negeri Semarang, Jurusan IImu Kesehatan Masyrakat.

Grieve, D. and Pheasant, S. (1982). Biomechanics. In W.T. Singleton (ed.) The body at work. Cambridge University press

McAtamney, L., \& Corlett, E. N. (1993, April 2). RULA: a survey method for the investigation of work-related upper limb disorders. Applied Ergonomics, XXIV(2), 91-99.

Nurmianto E. 2008. Ergonomi Konsep Dasar dan Aplikasinya. Surabaya: Guna Widya.

Purwanto, W., Mulyati, G. T., \& Saroyo, P. (2004, October 9). Seminar Nasional : Ergonomi 2.

Tayyari, F., \& Smith, J. L. (1997). Occupational Ergonomics. London, United Kingdom: Chapman and Hall. 